\title{
Energy Consumption Monitoring Analysis for Residential, Educational and Public Buildings
}

\author{
Allan Hani, Teet-Andrus Koiv \\ Environmental Department, Tallinn University of Technology, Tallinn, Estonia. \\ Email: allan.hani@rkas.ee
}

Received June $2^{\text {nd }}, 2012$; revised July 27 $7^{\text {th }}, 2012$; accepted August $5^{\text {th }}, 2012$

\begin{abstract}
In the present article thermal and electrical energy consumptions for different types of buildings are analyzed. The latitude and longitude of the researched area are defined $59^{\circ} 00^{\prime} \mathrm{N}$ and $26^{\circ} 00^{\prime} \mathrm{E}$. According to Köppen climate classification the area is located in warm summer continental climate. The study consist 40 residential, 7 educational and 44 public buildings. Three years data for each building type among 2006-2011 was used. Several detailed energy balances are presented for apartment buildings. In addition the different ways of domestic hot water preparation are analyzed for apartment buildings. The school buildings average consumption values are represented in study. Also valuable information of measured electrical energy consumption balance for a new office building is presented. Finally there is included the energy consumption analysis of public buildings.
\end{abstract}

Keywords: Specific Energy Consumption; Thermal Energy; Electrical Energy; Residential Buildings; Educational Buildings; Office Buildings

\section{Introduction}

He energy prices are rising continuously in most countries all over the world. Currently the targets are to consume less energy and produce more green energy. The building sector is responsible for approximately $40 \%$ consumption from total countries energy balances in EU and USA. In developing countries the value is around $20 \%$. A comprehensive research conclusion is presented in 2007 [1]. The biggest consumers of non-domestic buildings sector are supermarkets, hospitals, restaurants. The research of urban energy consumption distribution in USA [2] shows the variety of residential, public and industrial buildings energy consumption. Also energy balances for residential and public buildings are presented. The electrical energy consumption in public buildings is a concern. London public buildings have been researched $[3,4]$ — the office buildings specific energy consumption values range is wide. In addition, a scenario of energy consumption in London until 2050 is presented. Similar scenarios could be suggested also to other countries. Statistical analysis of Chinese buildings has been carried out in some extent $[5,6]$. The dispersion diagrams are presented (offices, hotels, governmental buildings). The Malaysian office buildings are compared with other countries [7]. Also the results of electrical motor variable speed drives economical calculation are carried out and the solution can be suggested. The calculated energy consumptions and real measurement result differ 1.2 - 1.5 times in lots of cases $[8,9]$. The calculation methods must be revised. To have more precise calculation results the iterative calibration process for dynamic simulations is prepared [10]. Already in 2002 an envelope shape and other building parameters based strategies have been suggested for designing low energy office buildings [11]. This information is valuable and can be used by architects, engineers and design companies. In China the trends for heating and cooling energy consumption in different climate areas are researched. The scenario for period 2009-2100 is presented [12]. To lower a cooling load and glaring of the light in buildings the windows can be coated with protective films [13]. The solution suits well for the older buildings. A very interesting research of LEED certification effects to energy consumption is done in North America [14]. Averagely LEED buildings consume $18 \%$ - 39\% less energy per floor area than others. But 28\% - 35\% LEED buildings consume more energy per floor area than others. To lower the ventilation air exchange rates reduces energy consumption. A good solution is to use $8 \mathrm{l} / \mathrm{s}$ per person and lower the ventilation rate when absent [15]. The energy saving measures shall be selected according to the building.

\section{Methods}

\subsection{The Compensation of External Air Temperature Variety for Different Years Heat Consumption}

The degree-days are widely used to eliminate the influ- 
ence of external air temperature difference for different years to heat energy consumption. The heat energy consumption is reduced to reference year basis. The reference year degree-days in Estonia are selected from 19752004 (30-year period) and defined for six different locations (Tallinn, Tartu, Jõhvi, Pärnu, Valga, Ristna).

Determination of degree-day reference year

Following Equation (1) expresses the equation for degree-day reference year creation [16].

$$
S=\sum_{i=1}^{n}\left(t_{B}-t_{\mathrm{EXTi}}\right) \times \delta_{i}
$$

where, $S$ is number of degree-days, ${ }^{\circ} \mathrm{K} \cdot \mathrm{d}$; $n$ is number of days (in a month or a year); $t_{B}$ is internal air temperature (balance temperature), ${ }^{\circ} \mathrm{C} ; t_{\mathrm{EXTi}}$ is external air temperature of $i$ day, ${ }^{\circ} \mathrm{C} ; \delta_{i}=1$, if $t_{B}>t_{\mathrm{EXTi}} ; \delta_{i}=0$, if $t_{B} \leq t_{\mathrm{EXTi}}$

Determination of heat energy consumption normalized with reference year

The following Equation (2) is used to eliminate the influence of external air temperature to heat energy.

$$
Q_{n}=\left(Q_{\mathrm{REAL}}-C\right) \times \frac{S_{N}}{S_{\mathrm{REAL}}}+C
$$

where, $Q_{n}$ is heat consumption normalized with reference year, $\mathrm{MWH} /$ year; $Q_{\mathrm{REAL}}$ is heat consumption of real year, $\mathrm{MWH} /$ year; $S_{N}$ is degree-days of reference year, ${ }^{\circ} \mathrm{K} \cdot \mathrm{d}$; $S_{\mathrm{REAL}}$ is degree-days of real year, ${ }^{\circ} \mathrm{K} \cdot \mathrm{d}$; $C$ is heat consumption where degree-days do not have affect (e.g. hot water), MWH/year.

The actual research heat energy consumption values are normalized according to Equation (2). In addition the electrical energy consumption is added.

\subsection{Degree-Day Energy Consumption Calculations with Variable Balance Temperature}

The method is also expressed in [16].

Determination of free heat in residential building

The sources of free heat in the building are people, electric devices, electric lightning, and solar radiation. The main components of the free heat load are calculated by the Equation (3).

$$
\Phi_{\mathrm{AFH}}=\Phi_{\mathrm{PEOP}}+\Phi_{\mathrm{LIGHT}}+\Phi_{\mathrm{EQUIP}}+\Phi_{\mathrm{SOLAR}}
$$

where, $\Phi_{\mathrm{AFH}}$ is the average free heat load, $\mathrm{kW} ; \Phi_{\text {PEOP }}$ is the people average effective free heat load, $\mathrm{kW} ; \Phi_{\text {LIGHT }}$ is the electric lighting average effective free heat load, $\mathrm{kW}$; $\Phi_{\text {EQUIP }}$ is the average effective free heat load of equipments, $\mathrm{kW}$; $\Phi_{\text {SOLAR }}$ is the average effective free heat load due to the solar radiation, $\mathrm{kW}$.

The respective free heat loads $\Phi_{\text {free }}$ are determined by the amounts of free heat energy $Q_{\text {free }}$ and the duration of the respective period $\tau(4)$.

$$
\Phi_{\text {free }}=1000 \cdot \frac{Q_{\text {free }}}{\tau}
$$

where $Q_{\text {free }}$ is the free heat energy of the building, MWH; $\tau$ is the duration of the period, h.

Determination of the balance temperature on the basis of free heat

On the basis of the degree days it is possible to calculate the heat requirements for heating the building by Equation (5)

$$
Q_{k}=H \cdot S_{N} \times 24 \times 10^{-3}
$$

where, $S_{N}$ is the number of degree-days corresponding to the balance temperature of the building; 24 is the number of hours in a day; $H$ is the specific heat losses, $\mathrm{kW} /{ }^{\circ} \mathrm{K}$, determined by Equation (6).

Specific heat losses of the building

$$
H=\sum_{i=1}^{n} U_{i} \cdot A_{i}+L \cdot c \cdot \rho
$$

where, $U_{i}$ is the U-value of envelope element $i$

$\mathrm{W} /\left(\mathrm{m}^{2} \cdot{ }^{\circ} \mathrm{K}\right) ; A_{i}$ is the area of envelope element $i, \mathrm{~m}^{2} ; n$ is the number of different envelope elements; $L$ is the air change, $\mathrm{m}^{3} / \mathrm{s} ; c$ is the specific heat of the air, $\mathrm{J} /\left(\mathrm{kg} \cdot{ }^{\circ} \mathrm{K}\right) ; \rho$ is the density of the air, $\mathrm{kg} / \mathrm{m}^{3}$.

To more precisely display the heat conservation obtained by renovation it is expedient to use the degree days with a variable balance temperature.

In renovating the building (e.g. insulating the envelope elements) the specific heat losses decrease and thus affect the balance temperature.

The internal air temperature of the building is made up by the heat provided by the heating system and free heat (7).

$$
t_{\text {int }}=t_{\text {ext }}+\Delta t_{\text {heat }}+\Delta t_{f h}
$$

Balance temperatures can be found by Equation (8)

$$
t_{B}=t_{\text {int }}-\Delta t_{f h}
$$

where, $t_{\text {int }}$ is internal air temperature; $t_{\mathrm{ext}}$ is the external air temperature; $t_{B}$ is the balance temperature; $\Delta t_{f h}$ is the rise in the temperature at the expense of the free heat taking part in the heat balance of the building.

The rise in the temperature at the expense of free heat can be found by Equation (9)

$$
\Delta t_{\text {fh }}=1000 \cdot \frac{\Phi_{\text {free }}}{H}
$$

The useful free heat load needed in determining the balance temperature is determined by Equation (10)

$$
\Phi_{\text {free }}=\Phi_{\text {drree }} \cdot \eta
$$

where, $\Phi_{\text {drree }}$ is the design free heat load, $\mathrm{W} ; \eta$ is the utilization factor.

The value of the utilization factor depends on the con- 
trol level of the heating system. (e.g. if the temperature of the heating systems' flow water is controlled by the external air temperature and the heat output of the radiators is controlled, we can acquaint more use of free heat than if we control only the temperature of the flow water). Based on balance temperature degree days the energy consumption balance can be calculated and evaluated with real measurement results. A decrease of the balance temperature brings remarkable savings in the heat requirements of the building. The method is used for apartment buildings thermal energy balance calculations and saving estimations. Nevertheless, for public buildings, where the $t_{B}$ varies remarkably during the year, dynamic simulations (IDA Indoor Climate and Energy, TRNSYS, Energy Plus, etc.) or real measurements for energy balance determination can be suggested.

\section{Results and Discussion}

\subsection{Residential Buildings}

Total 40 buildings thermal and electrical energy consumptions (2006-2010) were collected and analyzed. The detailed energy balance analysis was carried out for 14 buildings. Information about reconstructions, heating source, internal air temperature, air exchange rate and domestic hot water production is presented in Table 1.
Following abbreviations are used: DH-district heating; WB - wood fired boiler; GB-gas fired boiler; DHWdomestic hot water; $\mathrm{ACH}$ - air exchange rate; HS-heating substation; EL-electrical heaters; win-windows; bal—balancing works; full-full reconstruction.

During actual research the energy audits, prepared by professional auditors, were evaluated. In a numerous cases the systematic errors were found. DHW is prepared with decentralized electrical heaters, but the auditors have calculated once again the DHW energy consumption to heating energy balance and this is not correct. Among current energy balance calculations all the mistakes were corrected. Furthermore the packages of saving measures did not include ventilation reconstruction measures. This leads to the fact that among studied audits no ventilation improvement was done (2006-2010). The ventilation reconstruction problems shall be taken to the focus in further auditor trainings. The solutions with heat recovery (decentralized room or apartment based ventilation, and exhaust air heat pump) are available to use in reconstruction projects. In following Figures 1 and $\mathbf{2}$ the energy balances, specific gross consumptions and average specific consumptions of 14 apartment buildings are presented.

The Figures $\mathbf{1}$ and $\mathbf{2}$ the average specific energy consumptions:

Table 1. The main information about researched buildings.

\begin{tabular}{|c|c|c|c|c|c|c|c|}
\hline \multirow[t]{2}{*}{ Bld. } & \multirow[t]{2}{*}{ County } & \multicolumn{2}{|c|}{ Reconstructions } & \multirow[t]{2}{*}{ Heating source } & \multirow{2}{*}{$\begin{array}{c}\text { Tintavg } \\
\left.{ }^{\circ} \mathrm{C}\right]\end{array}$} & \multirow{2}{*}{$\begin{array}{c}\mathrm{ACH} \\
{[1 / \mathrm{h}]}\end{array}$} & \multirow[t]{2}{*}{ DHW } \\
\hline & & Envelope & Heating system & & & & \\
\hline A1 & Pärnu & - & - & $\mathrm{DH}$ & 20.0 & 0.40 & HS \\
\hline A2 & Harju & 2010 roof 300 mm, <2010 win 86\% & 2007 HS, 2008 bal & $\mathrm{DH}$ & 20.0 & 0.40 & HS \\
\hline A3 & Saare & 2006 roof 400 mm, 2007 win $66 \%$ & 2000 HS & $\mathrm{DH}$ & 22.5 & 0.27 & HS \\
\hline A4 & Tartu & 2001 win $100 \%$ & $2001 \mathrm{HS}$ & $\mathrm{DH}$ & 23.0 & 0.25 & HS \\
\hline A5 & Harju & $<2010$ win $85 \%$ & - & GB & 20.0 & 0.30 & HS \\
\hline A6 & Ida-Viru & <2010 win 54\%, walls 100 mm 36\% & 2003 HS, 2007 bal & $\mathrm{DH}$ & 20.5 & 0.20 & HS \\
\hline A7 & Harju & 2009 roof 200 mm, <2010 win 93\% & 1997 HS, bal & $\mathrm{DH}$ & 21.0 & 0.40 & HS \\
\hline A8 & Viljandi & $<2009$ win $89 \%$ & 2008 full & $\mathrm{DH}$ & 21.0 & 0.33 & HS \\
\hline A9 & Jõgeva & - & - & $\mathrm{DH}$ & 19.0 & 0.35 & EL \\
\hline A10 & Põlva & - & - & $\mathrm{DH}$ & 23.0 & 0.24 & EL \\
\hline A11 & Ida-Viru & $<2008$ win $47 \%$ & - & $\mathrm{DH}$ & 19.0 & 0.31 & EL \\
\hline A12 & Valga & $<2008$ win $63 \%$, doors & - & $\mathrm{DH}$ & 22.0 & 0.30 & EL \\
\hline A13 & Harju & <2009 win85\% & $<2009$ HS & $\mathrm{DH}$ & 21.0 & 0.20 & HS \\
\hline A14 & Tartu & $<2009$ win $77 \%$ & - & $\mathrm{DH}$ & 19.5 & 0.20 & EL \\
\hline
\end{tabular}




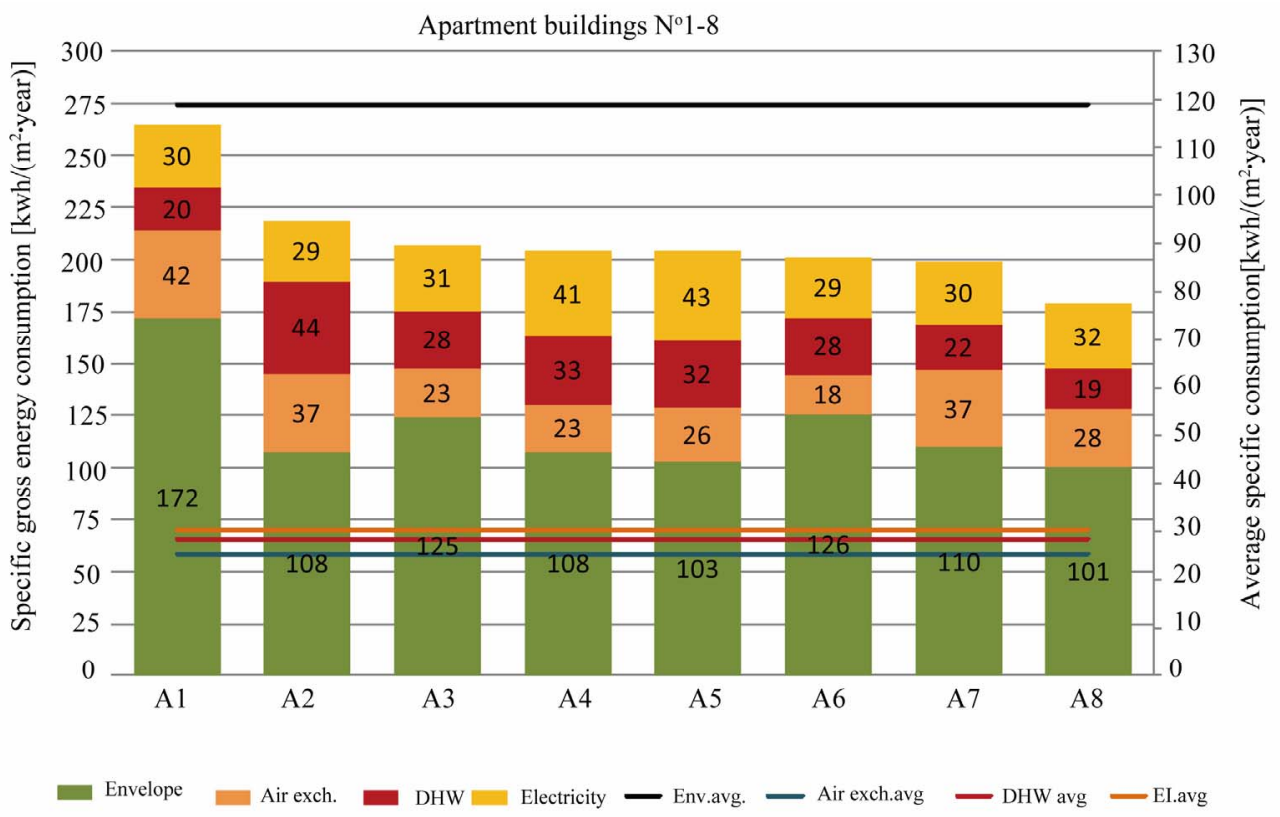

Figure 1. Dynamics of energy balance and specific energy consumption in the analyzed buildings (DHW prepared in substation).

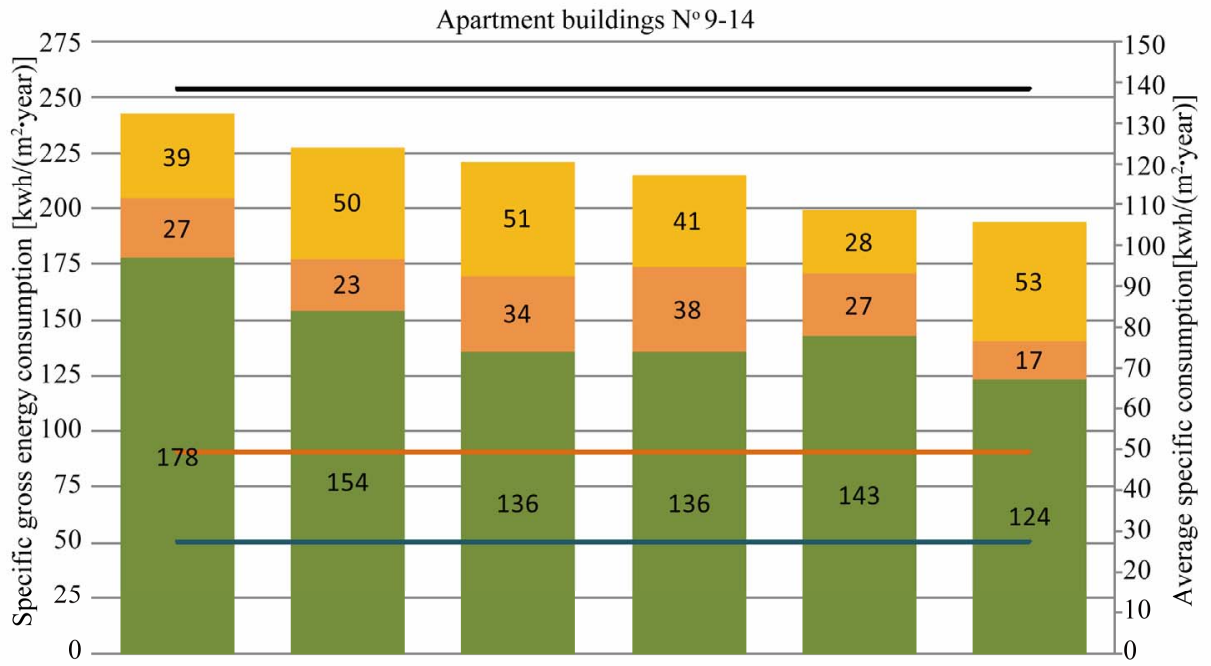

$$
\text { Envelope }- \text { Air exch. Electricity — Env.avg. — Air exch.avg —EI.avg }
$$

Figure 2. Dynamics of energy balance and specific energy consumption in the analyzed buildings (DHW prepared with electrical heaters in apartments).

1) Heating $120-140, \mathrm{kWh} /\left(\mathrm{m}_{\text {heated }}^{2} \cdot\right.$ year $)$;

2) Air exchange and infiltration 20 - 30, $\mathrm{kWh} /\left(\mathrm{m}_{\text {heated }}^{2} \cdot\right.$ year $)$;

3) Domestic hot water $30, \mathrm{kWh} /\left(\mathrm{m}_{\text {heated }}^{2} \cdot\right.$ year $)$;

4) Electricity 30 without electrical heaters, $\mathrm{kWh} /\left(\mathrm{m}_{\text {heated }}^{2} \cdot\right.$ year $)$;

5) Electricity 50 with electrical heaters, $\mathrm{kWh} /\left(\mathrm{m}_{\text {heated }}^{2} \cdot\right.$ year $)$;

6) Total $200-250, \mathrm{kWh} /\left(\mathrm{m}_{\text {heated }}^{2} \cdot\right.$ year $)$.
The heated area $\mathbf{m}^{2}$ is a basis for specific energy consumption values.

Earlier studies [17] have indicated average specific heating energy consumption of $185 \mathrm{kWh} /\left(\mathrm{m}^{2} \cdot\right.$ year). Current analyse results gave $180-185 \mathrm{kWh} /\left(\mathrm{m}^{2} \cdot\right.$ year) without electrical energy consumption.

The Figure 3 presents dispersion of specific thermal and electrical energy consumption for analyzed 40 apartment buildings. 


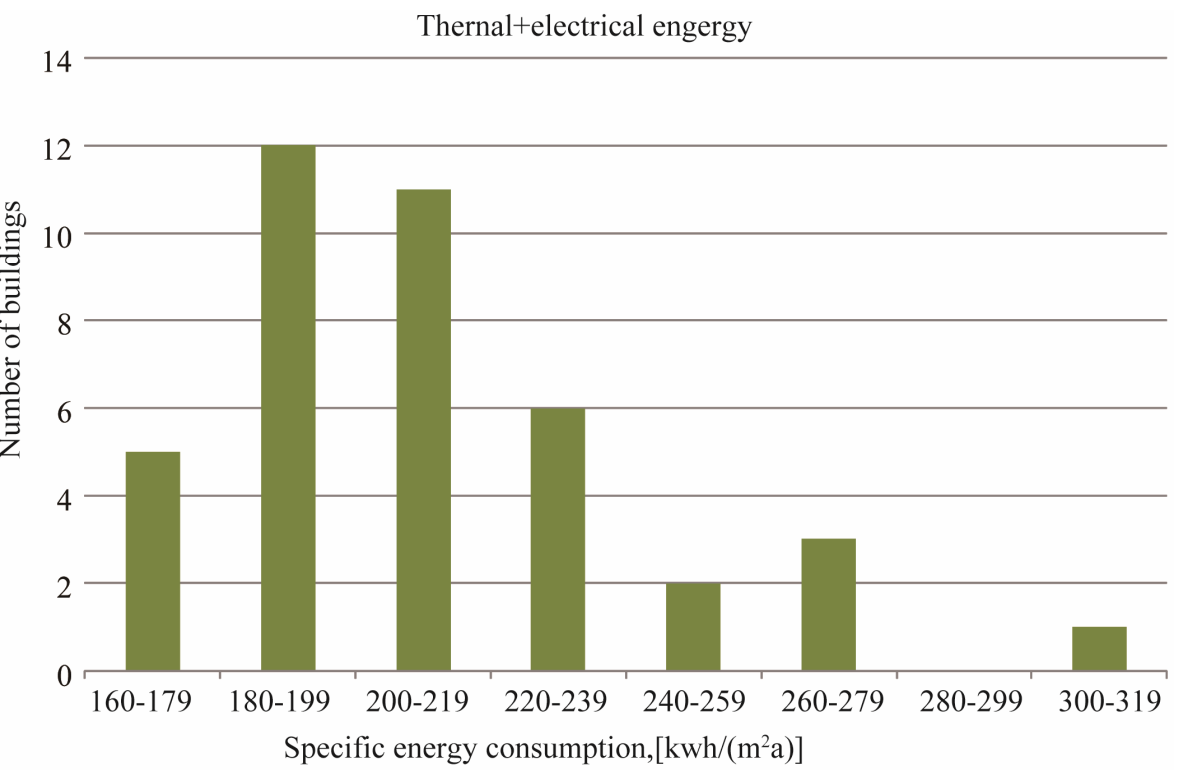

Figure 3. Dispersion of specific energy consumption of apartment buildings.

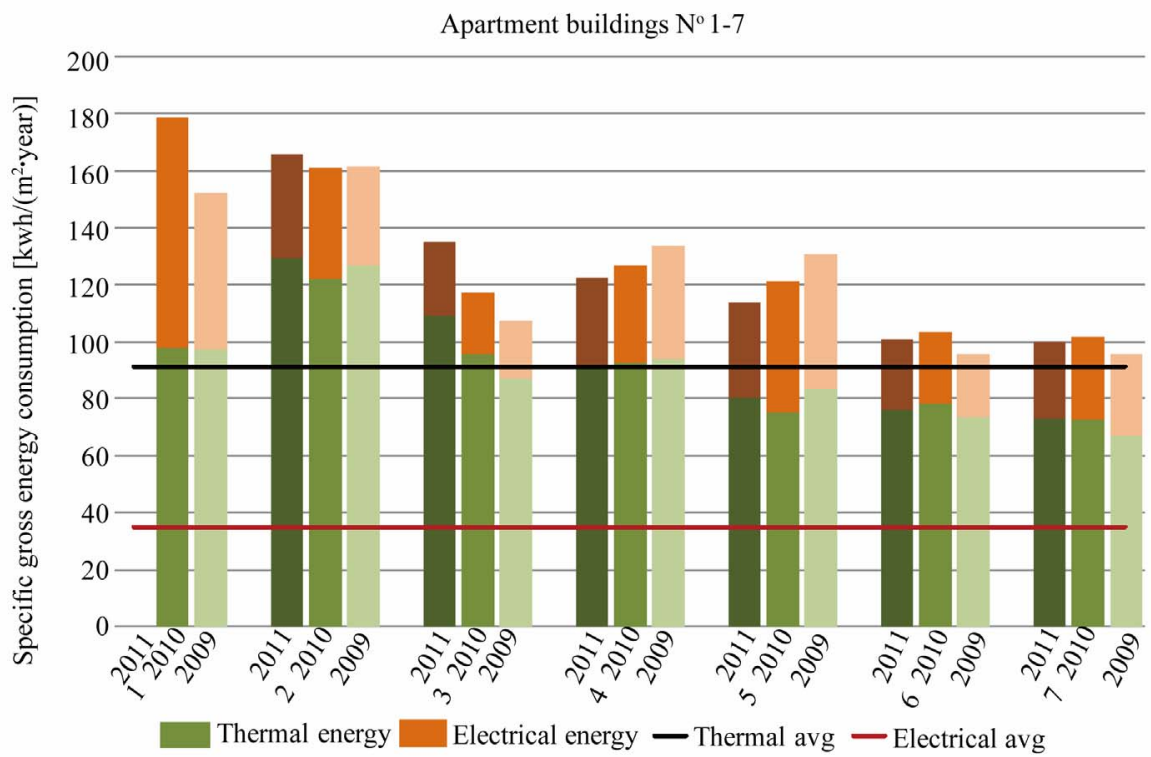

Figure 4. Specific energy consumption in the analyzed educational buildings.

Most of the apartment buildings energy consumption varies between $180-220 \mathrm{kWh} /\left(\mathrm{m}^{2} \cdot\right.$ year $)$.

\subsection{Educational buildings}

Total 7 school buildings thermal and electrical energy consumptions (2009-2011) were collected and analyzed. The heat energy consumption is normalized with reference year. Following Figure 4 presents the specific energy consumption of studied buildings.

The net area $\mathbf{m}^{2}$ is a basis for specific energy con- sumption values.

1) Average specific thermal energy consumption (includes DHW) is $90 \mathrm{kWh} /\left(\mathrm{m}_{\text {net }}^{2} \cdot\right.$ year $)$.

2) Average specific electrical energy consumption is $35 \mathrm{kWh} /\left(\mathrm{m}_{\text {net }}^{2} \cdot\right.$ year $)$.

3)Total $~ 125 \mathrm{kWh} /\left(\mathrm{m}_{\text {net }}^{2} \cdot\right.$ year $)$.

The specific consumption value is relatively low, but 3 months during the year the usage of school buildings is nearly 0 . Also, the net area in typical school buildings is ca 1.5 times bigger than heated area [18]. Furthermore, the current schools investment schematic supports the 
low energy consumption, but the poor indoor climate aspects shall be considered [19].

\subsection{Public Buildings}

Total 44 public buildings thermal and electrical energy consumptions (2009-2011) were collected and analyzed. In addition one typical new ten-storey office building electrical energy balance is analyzed more in deep.

Measured energy balance of an office building

The importance of electrical energy consumption in new office buildings is frequently underestimated in warm summer continental climate. Following Figure 5 represents the energy balance of a ten-storey office building. The measurements base on 2011 energy consumption.

The electrical energy balance (100\%) division:

1) Lighting and electrical equipment (10 floors) $42.2 \%$;

2) Cooling (chiller unit, pumps, dry-coolers, split-units) 27.6\%;

3) Servers $8.9 \%$;
4) Ventilation (fans, heating pumps, heat recovery wheel) $7.0 \%$;

5) External electrical heating (ramp heating, rainwater gullies) $4.7 \%$;

6) External and parking area lighting 3.3\%;

7) Technical rooms and video surveillance $2.8 \%$;

8) Heating substation (boilers, pumps) 2.2\%;

9) Elevators $1.3 \%$.

The analysis of 44 public buildings

It is more complicated to evolve energy saving measures in public building sector than in residential buildings. The national heritage board has grounded restrictions to public buildings envelope and finishing. The internal insulation can not be added due to climatic conditions. Windows change is whether expensive or not allowed. As well the heating system reconstruction is more complicated (employees and equipment have to be moved; valuable finishing materials can be destroyed; more expensive heating elements are required by architect, etc.).

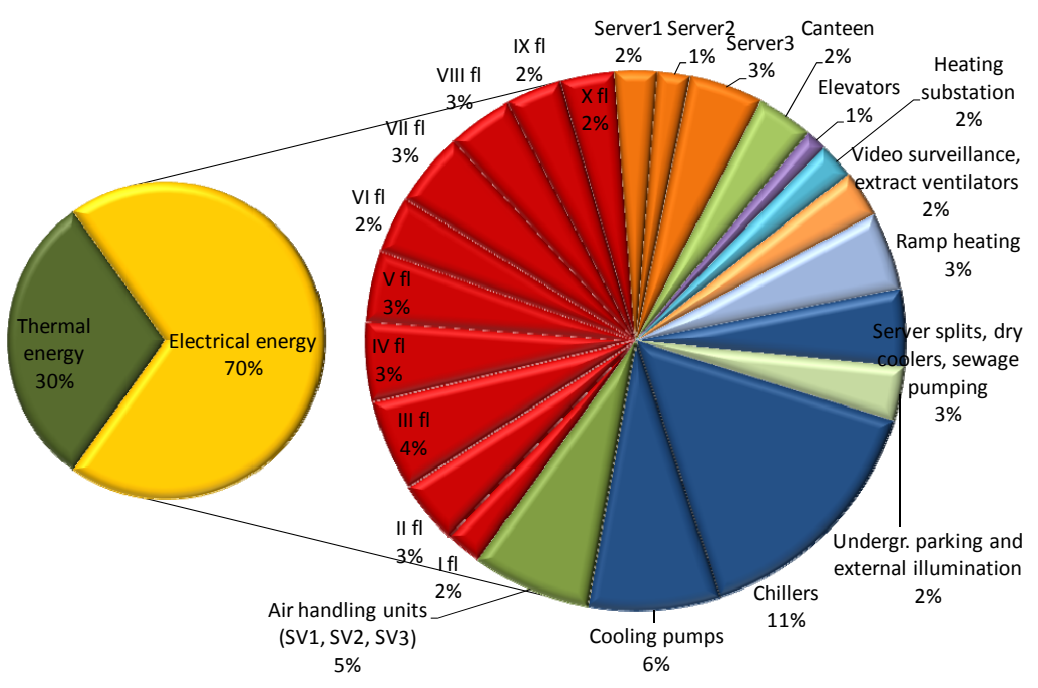

Figure 5. Measured energy balance of a high rise office building.

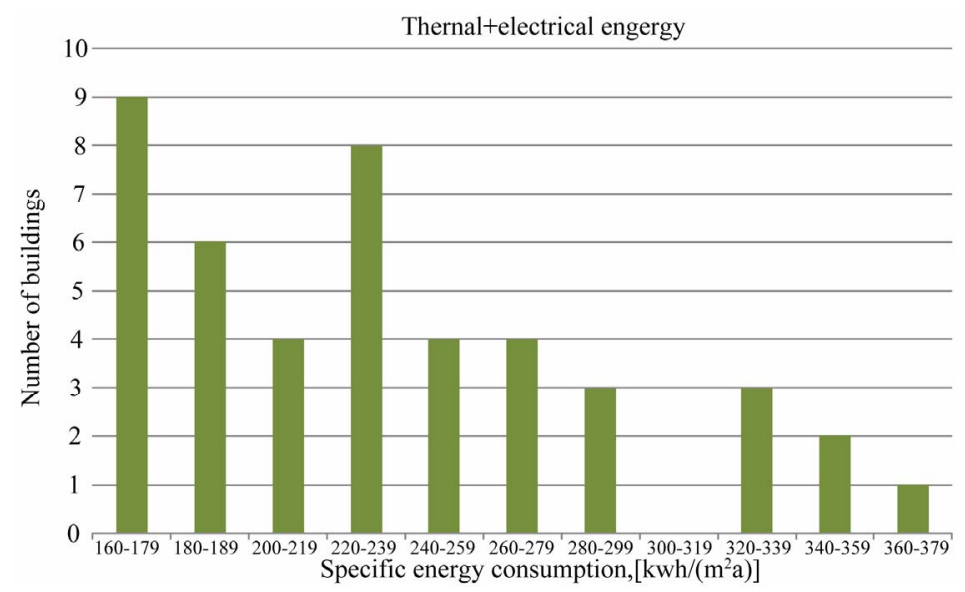

Figure 6. Dispersion of specific energy consumption of public buildings. 
Usually roof insulation is the easiest saving measure to be done.

The current analysis is based on 44 public buildings thermal and electrical energy consumption. The heat energy consumption is normalized with reference year. The net area $\mathbf{m}^{2}$ is a basis for specific energy consumption values. In following Figure 6 the dispersion of specific energy consumption of analysed buildings is presented.

The energy consumption varies widely and the energy saving measures can be worked out only case by case.

Average share of thermal energy is $60 \%$ and electrical $40 \%$ in public buildings. In 10 cases the electrical energy consumption was $25 \%$.

Among the study 4 buildings were electrically heated and their energy consumptions rating were in $12^{\text {th }}, 28^{\text {th }}$, $34^{\text {th }}$ and $38^{\text {th }}$ position in a regressive row. Nevertheless, the electrical energy is more expensive than other energy resources.

\section{Conclusions}

Based on the analysis of the energy consumption of residential, educational and public buildings following findings can be categorized:

\section{Residential buildings}

1) Reconstructions have been carried out without ventilation improvement. To maintain normal energy consumption heat recovery ventilation must be designed;

2) The energy balance calculations of energy auditors include occasionally errors in DHW handling.

3) The energy consumption for DHW preparation is lower with electrical heating compared to district heating. Nevertheless, the electrical energy is more expensive.

4) In several cases slight under-heating appears $\left(t_{\text {int }}=\right.$ $\left.20^{\circ} \mathrm{C}\right)$.

5) Reconstruction works have lowered energy cosumption averagely to $180-220 \mathrm{kWh} /\left(\mathrm{m}^{2} \cdot\right.$ year).

Educational buildings

1) The heated area $\mathrm{m}^{2}$ information is usually not available. In further research this information shall be collected. Based on the net area the energy consumption values are relatively low.

2) The ventilation systems are not working properly due to lack of maintenance knowledge and control possibilities.

3) In several occasions the investment model for schools directs to extreme energy saving. The poor indoor climate or energetically inefficient window opening (air exchange without heat recovery) is the result.

4) Simple building management systems for heating substations and ventilation systems are suggested.

5) More attention must be paid to educational buildings energy efficient use and reconstructions.

Public buildings

1) There are mainly two types of buildings: very old cultural heritage buildings and new office buildings.

2) For old cultural heritage buildings the envelope reconstruction measures can be almost excluded (in some cases window, door replacement and roof insulation can be suggested).

3) Heat recovery ventilation has been installed in most of the cases.

4) In new office building the electrical energy consumption was $70 \%$ of total energy consumption. The biggest electrical energy consumers were cooling system and server rooms. The ramp heating set parameters shall be also adjusted. In design phase the ventilation air exchange rates must be selected conservatively, but the capacity of air handling units and main ducts shall be selected with reservations. Furthermore, meeting rooms location selection shall be well considered and VAV systems designed.

5) Free cooling parameter adjustment according to real room temperatures must be carried out.

6) Due to variable balance temperature during the year the degree-day calculation method can not be used for energy balance calculations. Minimally dynamic simulation with validated consumption values is suggested.

7) The variation of public buildings specific energy consumption is wide. Therefore systematic monitoring of energy consumption and energy saving plan for each building shall be suggested.

\section{Acknowledgements}

Estonian Ministry of Education and Research is greatly acknowledged for funding and supporting this study. European Social Foundation financing task 1.2.4 Cooperation of Universities and Innovation Development, Doctoral School Project "Civil Engineering and Environmental Engineering” code 1.2.0401.09-0080 has made publishing of this article possible.

\section{REFERENCES}

[1] L. Pérez-Lombard, J. Ortiz and C. Pout, "A Review on Buildings Energy Consumption Information,” Energy and Buildings, Vol. 40, No. 3, 2008, pp. 394-398. doi:10.1016/j.enbuild.2007.03.007

[2] B. Howard, L. Parshall, J. Thompson, S. Hammer, J. Dickinson and V. Modi, "Spatial Distribution of Urban Building Energy Consumption by End Use,” Energy and Buildings, Vol. 45, 2012, pp. 141-151. doi:10.1016/j.enbuild.2011.10.061

[3] M. Kolokotroni, X. Ren, M. Davies and A. Mavrogianni, "London's Urban Heat Island: Impact on Current and Future Energy Consumption in Office Buildings,” Energy and Buildings, Vol. 47, 2012, pp. 302-311. doi:10.1016/j.enbuild.2011.12.019

[4] R. Choudhary, "Energy Analysis of the Non-Domestic Building Stock of Greater London,” Building and Envi- 
ronment, Vol. 51, 2012, pp. 243-254. doi:10.1016/j.buildenv.2011.10.006

[5] H. Xiao, Q. P. Wei and Y. Jiang, "The Reality and Statistical Distribution of Energy Consumption in Office Buildings in China," Energy and Buildings, Vol. 50, 2012, pp. 259-265. doi:10.1016/j.enbuild.2012.03.048

[6] J. Zhao, Y. J. Xin and D. D. Tong, "Energy Consumption Quota of Public Buildings Based on Statistical Analysis,” Energy Policy, Vol. 43, 2012, pp. 362-370. doi:10.1016/j.enpol.2012.01.015

[7] R. Saidur, "Energy Consumption, Energy Savings, and Emission Analysis in Malaysian Office Buildings," Energy Policy, Vol. 37, No. 10, 2009, pp. 4104-4113. doi:10.1016/j.enpol.2009.04.052

[8] O. Morck, K. E. Thomsen and J. Rose, “The EU CONCERTO Project Class 1-Demonstrating Cost-Effective Low-Energy Buildings-Recent Results with Special Focus on Comparison of Calculated and Measured Energy Performance of DANISH Buildings,” Applied Energy, Article in Press, 2012.

[9] K. E. Thomsen, J. M. Schultz and B. Poel, "Measured Performance of 12 Demonstration Projects-IEA Task 13 'Advanced Solar Low Energy Buildings',' Energy and Buildings, Vol. 37, No. 2, 2005, pp. 111-119. doi:10.1016/j.enbuild.2004.01.036

[10] P. Raftery, M. Keane and A. Costa, "Calibrating Whole Building Energy Models: Detailed Case Study Using Hourly Measured Data,” Energy and Buildings, Vol. 43, No. 12, 2011, pp. 3666-3679. doi:10.1016/j.enbuild.2011.09.039

[11] E. Gratia and A. De Herde, "Design of Low Energy Office Buildings,” Energy and Buildings, Vol. 35, No. 5, 2003, pp. 473-491. doi:10.1016/S0378-7788(02)00160-3
[12] K. K. W. Wan, D. H. W. Li, D. L. Liu and J. C. Lam, "Future Trends of Building Heating and Cooling Loads and Energy Consumption in Different Climates," Building and Environment, Vol. 46, No. 1, 2011, pp. 223-234. doi:10.1016/j.buildenv.2010.07.016

[13] D. H. W. Li, T. N. T. Lam, S. L. Wong and E. K. W. Tsang, "Lighting and Cooling Energy Consumption in an Open-Plan Office Using Solar Film Coating," Energy, Vol. 33, No. 8, 2008, pp. 1288-1297. doi:10.1016/j.energy.2008.03.002

[14] G. R. Newsham, S. Mancini and B. J. Birt, "Do LEEDCertified Buildings Save Energy? Yes, But...,” Energy and Buildings, Vol. 41, No. 8, 2009, pp. 897-905. doi:10.1016/j.enbuild.2009.03.014

[15] W. J. Fisk, D. Black and G. Brunner, "Changing Ventilation Rates in US Offices: Implications for Health, Work Performance, Energy, and Associated Economics,” Building and Environment, Vol. 47, 2012, pp. 368-372. doi:10.1016/j.buildenv.2011.07.001

[16] T.-A. Koiv, “Estonian Degree-Days,” Tallinn, 2007.

[17] A. Hani, T.-A. Koiv, H. Voll and M. Tali, "Energy Efficiency in Residential Buildings. The Comparison between Degree Day Calculation and Simulations," Proceedings of the 2nd International Scientific "Energy and Climate Change" Conference, Athens, 8-9 October 2009, pp. 209213.

[18] T.-A. Koiv, "Estonian Government Ordinance No. 258, 2007 Minimum Requirements for Buildings Energy Performance Additional Analysis,” Tallinn, 2009.

[19] A. Hani, T.-A. Koiv and A. Mikola, "Ventilating with Room Units in Educational Institutions,” International Journal of Energy and Environment, Vol. 5, No. 5, 2011, pp. 629-636. 